Keywords: $D W P F$

Glass

Sludge Batch 6

Retention: Permanent

\title{
Analysis of DWPF Sludge Batch 6 (Macrobatch 7) Pour Stream Glass Samples
}

\author{
F.C. Johnson
}

February 2012

Savannah River National Laboratory Savannah River Nuclear Solutions, LLC Aiken, SC 29808

Prepared for the U.S. Department of Energy under contract number DE-AC09-08SR22470.

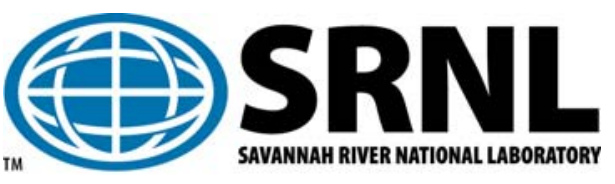


SRNL-STI-2011-00555

Revision 0

\section{DISCLAIMER}

This work was prepared under an agreement with and funded by the U.S. Government. Neither the U.S. Government or its employees, nor any of its contractors, subcontractors or their employees, makes any express or implied:

1. warranty or assumes any legal liability for the accuracy, completeness, or for the use or results of such use of any information, product, or process disclosed; or

2. representation that such use or results of such use would not infringe privately owned rights; or

3. endorsement or recommendation of any specifically identified commercial product, process, or service.

Any views and opinions of authors expressed in this work do not necessarily state or reflect those of the United States Government, or its contractors, or subcontractors.

\section{Printed in the United States of America \\ Prepared for \\ U.S. Department of Energy}


Keywords: $D W P F$

Glass

Sludge Batch 6

Retention: Permanent

\title{
Analysis of DWPF Sludge Batch 6 (Macrobatch 7) Pour Stream Glass Samples
}

\author{
F.C. Johnson
}

January 2012

Savannah River National Laboratory

Savannah River Nuclear Solutions, LLC Aiken, SC 29808

Prepared for the U.S. Department of Energy under contract number DE-AC09-08SR22470.

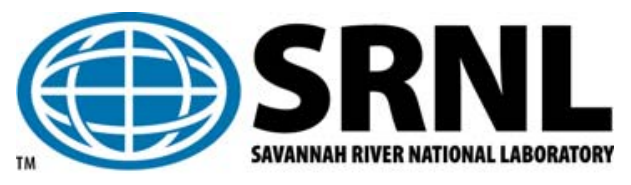




\section{REVIEWS AND APPROVALS}

AUTHORS:

F.C. Johnson, Process Technology Programs

Date

TECHNICAL REVIEW:

D.K. Peeler, Process Technology Programs

Date

C.L. Crawford, Process Technology Programs

Date

APPROVAL:

C.C. Herman, Manager

Date

Process Technology Programs

S.L. Marra, Manager

Date

Environmental \& Chemical Process Technology Research Programs

J.E. Occhipinti, Manager

Date

Waste Solidification Engineering 


\section{ACKNOWLEDGEMENTS}

The author would like to acknowledge the support provided by Amanda Billings and John Pareizs for testing and sampling in the Shielded Cells, the Shielded Cells Organization (Phyllis Burkhalter, Dee Wheeler, Rita Sullivan, Jane Howard and Monica Jenkins) as well as SRNL Analytical Development personnel (Damon Click, Boyd Wiedenman, Mark Jones, David Missimer, Ronnie Rutherford, Beverly Burch, and Loretta Farrow) for the chemical analysis and X-ray diffraction data. 
SRNL-STI-2011-00555

Revision 0

\section{EXECUTIVE SUMMARY}

The Defense Waste Processing Facility (DWPF) began processing Sludge Batch 6 (SB6), also referred to as Macrobatch 7 (MB7), in June 2010. SB6 is a blend of the heel of Tank 40 from Sludge Batch 5 (SB5), H-Canyon Np transfers and SB6 that was transferred to Tank 40 from Tank 51. SB6 was processed using Frit 418.

During processing of each sludge batch, the DWPF is required to take at least one glass sample to meet the objectives of the Glass Product Control Program and to complete the necessary Production Records so that the final glass product may be disposed of at a Federal Repository. Four pour stream glass samples and two Melter Feed Tank (MFT) slurry samples were collected while processing SB6. The samples were transferred to the Savannah River National Laboratory (SRNL) where they were analyzed. The following conclusions were drawn from the analytical results provided in this report:

- The sum of oxides for the official SB6 pour stream glass is within the Product Composition Control System (PCCS) limits (95-105 wt\%).

- The average calculated Waste Dilution Factor (WDF) for SB6 is 2.3. In general, the measured radionuclide content of the official SB6 pour stream glass is in good agreement with the calculated values from the Tank 40 dried sludge results from the SB6 Waste Acceptance Product Specification (WAPS) sample; however, the measured value of Cs137 is an order of magnitude higher than calculated, which is expected since the Tank 40 sample does not account for salt addition.

- As in previous pour stream samples, ruthenium and palladium inclusions were detected by Scanning Electron Microscopy (SEM)-Electron Dispersive Spectroscopy (EDS) in the official SB6 pour stream sample.

- The Product Consistency Test (PCT) results indicate that the official SB6 pour stream glass meets the waste acceptance criteria for durability with a normalized boron release of $0.69 \mathrm{~g} / \mathrm{L}$, which is an order of magnitude less than the Environmental Assessment (EA) glass.

- The measured density of the SB6 pour stream glass was in the range of $2.5-2.6 \mathrm{~g} / \mathrm{cm}^{3}$.

- The $\mathrm{Fe}^{2+} / \sum \mathrm{Fe}$ ratio of the SB6 pour stream samples were in the range of $0.25-0.41$, while the MFT-558 sample was in the range of $0.44-0.50$ and the MFT-568A sample was in the range of $0.02-0.16$. 


\section{TABLE OF CONTENTS}

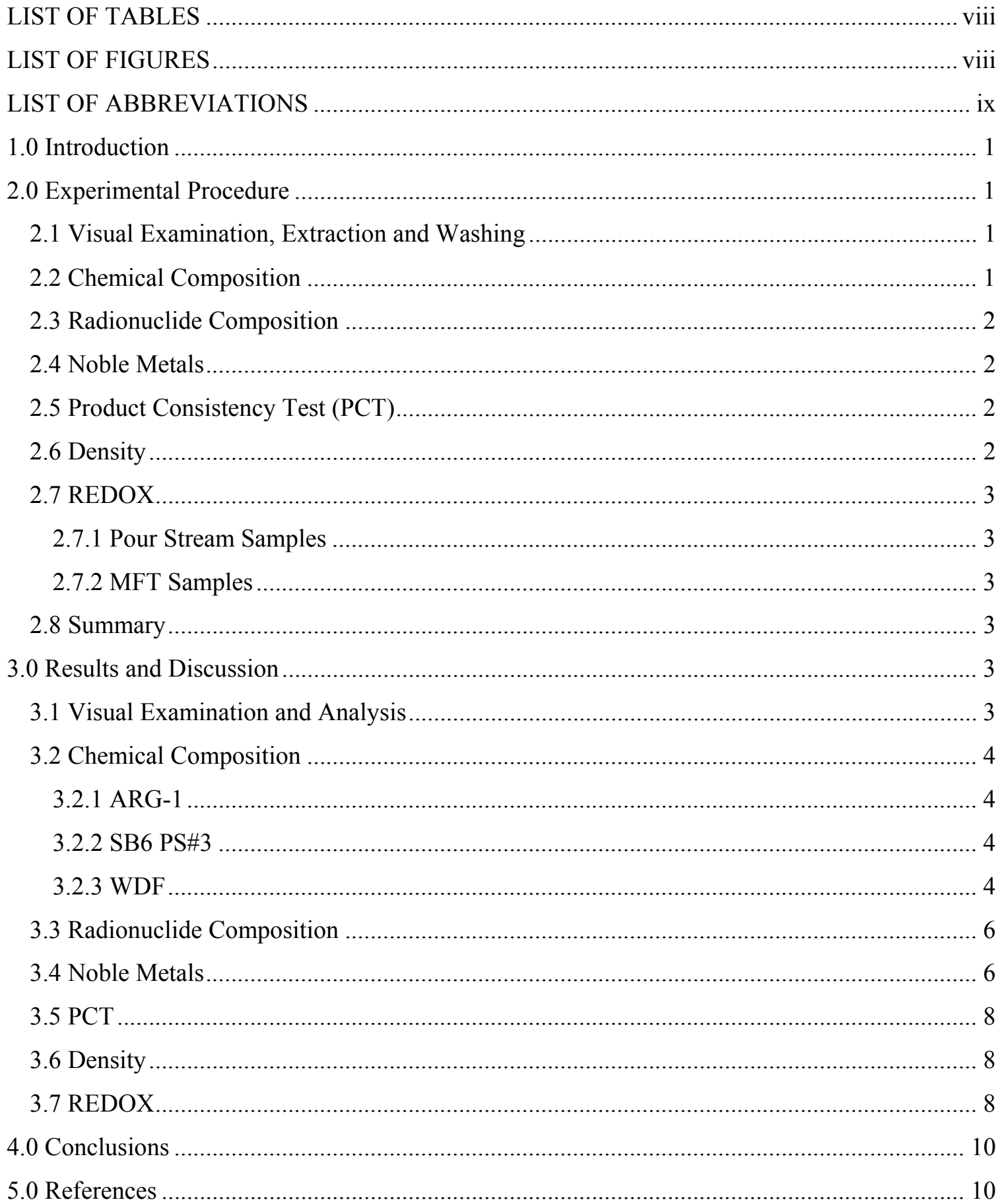




\section{LIST OF TABLES}

Table 1-1. DWPF Pour Stream Glass Sample Information......................................................... 1

Table 2-1. Summary of SB6 Pour Stream Glass Analyses........................................................... 3

Table 3-1. Analysis of Glass Surface Rinse Water .................................................................... 4

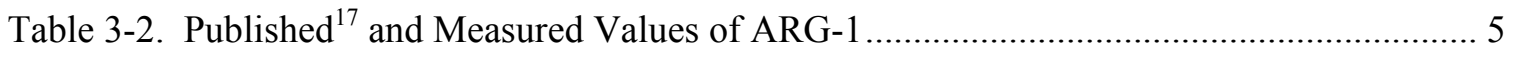

Table 3-3. Average Measured Composition of SB6 PS\#3 …..................................................... 5

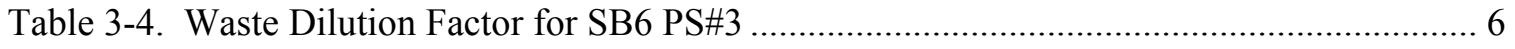

Table 3-5. Reportable Radionuclide Content of the SB6 PS\#3 Glass ......................................... 7

Table 3-6. Noble Metal Concentration in the SB6 PS\#3 Glass .................................................... 8

Table 3-7. Normalized PCT Results for SB6 PS\#3 (g/L) ........................................................ 9

Table 3-8. SB6 Pour Stream Glass REDOX Data........................................................................ 9

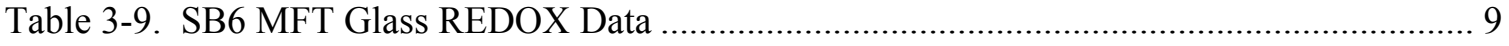

Table 5-1. Measured Elemental Concentrations $(\mu \mathrm{g} / \mathrm{g})$ for Glasses Prepared Using an Aqua

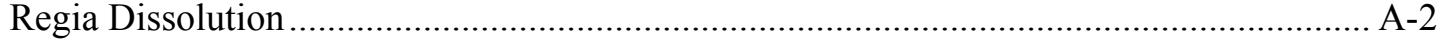

Table 5-2. Measured Elemental Concentrations ( $\mu \mathrm{g} / \mathrm{g}$ ) for Glasses Prepared Using a Peroxide

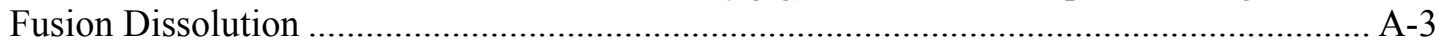

Table 5-3. Measured Radionuclide Concentrations (dpm/g) via Gamma and Beta Counting and

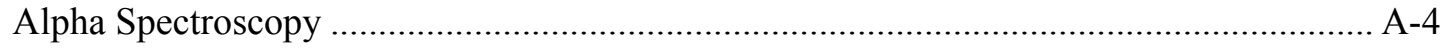

Table 5-4. Measured Concentrations of $\mathrm{m} / \mathrm{z}(\mu \mathrm{g} / \mathrm{g})$ via ICP-MS ............................................. A-5

Table 5-5. As-Received and Adjusted Measurements of the PCT Solutions ............................ A-6

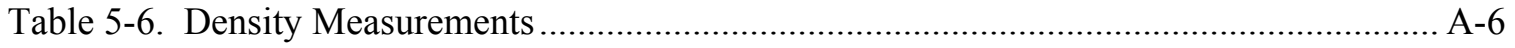

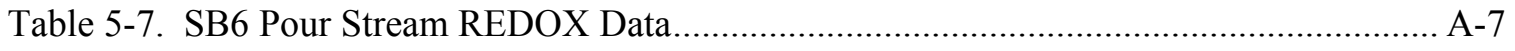

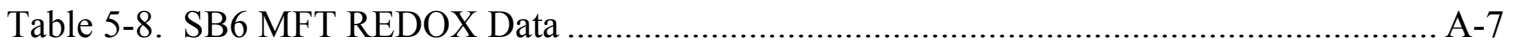

\section{LIST OF FIGURES}

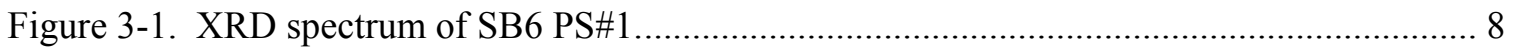




\section{LIST OF ABBREVIATIONS}

$\begin{array}{ll}\text { AD } & \text { Analytical Development } \\ \text { AR } & \text { Aqua Regia } \\ \text { ARG-1 } & \text { Analytical Reference Glass 1 } \\ \text { ARM } & \text { Approved Reference Material } \\ \text { ASP } & \text { Analytical Study Plan } \\ \text { CPC } & \text { Chemical Processing Cell } \\ \text { DWPF } & \text { Defense Waste Processing Facility } \\ \text { EA } & \text { Environmental Assessment } \\ \text { EDS } & \text { Electron Dispersive Spectroscopy } \\ \text { IC } & \text { Ion Chromatography } \\ \text { ICP-AES } & \text { Inductively Coupled Plasma - Atomic Emission Spectroscopy } \\ \text { ICP-MS } & \text { Inductively Coupled Plasma - Mass Spectrometry } \\ \text { MB7 } & \text { Macrobatch 7 } \\ \text { MFT } & \text { Melter Feed Tank } \\ \text { PCCS } & \text { Product Composition Control System } \\ \text { PCT } & \text { Product Consistency Test } \\ \text { PF } & \text { Peroxide Fusion } \\ \text { PS } & \text { Pour Stream } \\ \text { REDOX } & \text { REDuction/OXidation } \\ \text { RSD } & \text { Relative Standard Deviation } \\ \text { SB } & \text { Sludge Batch } \\ \text { SEM } & \text { Scanning Electron Microscopy } \\ \text { SME } & \text { Slurry Mix Evaporator } \\ \text { SRAT } & \text { Sludge Receipt Adjustment Tank } \\ \text { SRNL } & \text { Savannah River National Laboratory } \\ \text { St. Dev. } & \text { Standard Deviation } \\ \text { THERMO } & \text { Thermodynamic Hydration Energy Reaction MOdel } \\ \text { TTQAP } & \text { Task Technical and Quality Assurance Plan } \\ \text { WAPS } & \text { Waste Acceptance Product Specification } \\ \text { WDF } & \text { Waste Dilution Factor } \\ \text { XRD } & \text { X-ray Diffraction } \\ & \end{array}$




\subsection{Introduction}

The Defense Waste Processing Facility (DWPF) began processing Sludge Batch 6 (SB6), also referred to as Macrobatch 7 (MB7), in June 2010. SB6 is a blend of the heel of Tank 40 from Sludge Batch 5 (SB5), H-Canyon Np transfers and SB6 that was transferred to Tank 40 from Tank 51. ${ }^{1}$ SB6 was processed using Frit 418.,3

Sludge is received into the DWPF Chemical Processing Cell (CPC) and is processed through the Sludge Receipt and Adjustment Tank (SRAT) and Slurry Mix Evaporator Tank (SME). The treated sludge slurry is then transferred to the Melter Feed Tank (MFT) and fed to the melter. During processing of each sludge batch, the DWPF is required to take at least one glass sample to meet the objectives of the Glass Product Control Program ${ }^{4}$ (GPCP) and to complete the necessary Production Records so that the final glass product may be disposed of at a Federal Repository.

The DWPF requested various analyses of radioactive glass samples obtained from the melter pour stream during processing of SB6 as well as reduction/oxidation (REDOX) analysis of MFT samples to determine the impact of Argon bubbling. ${ }^{5}$ Sample analysis followed the Task Technical and Quality Assurance Plan (TTQAP) ${ }^{6}$ and an Analytical Study Plan (ASP). ${ }^{7}$ Four Pour Stream (PS) glass samples and two MFT slurry samples ${ }^{a}$ were delivered to the Savannah River National Laboratory (SRNL) from the DWPF. Table 1-1 lists the sample information for each pour stream glass sample. SB6 PS\#3 (S03472) was selected as the official pour stream sample for SB6 and full analysis was requested. This report details the visual observations of the as-received SB6 PS\#3 glass sample as well as results for the chemical composition, Product Consistency Test (PCT), radionuclide content, noble metals, and glass density. REDOX results will be provided for all four pour stream samples and vitrified samples of MFT-558 and MFT568A. Where appropriate, data from other pour stream samples will be provided.

It should be noted that the SB6 PS\#2 sample (collected while filling glass canister S03469) was designated as the archive sample and will be placed in Primary Container 106 (PC0106). Limited analyses were requested from this sample, so the remaining glass in the Pt-Au collection boat will be archived.

Table 1-1. DWPF Pour Stream Glass Sample Information

\begin{tabular}{|c|c|c|c|}
\hline Glas s Canister & Sample Date & MFT Batch & Sample ID \\
\hline S03465 & Dec-10 & 549 & SB6 PS\#1 \\
\hline S03469 & Dec-10 & 550 & SB6 PS\#2 \\
\hline S03472 & Dec-10 & 551 & SB6 PS\#3 \\
\hline S03506 & Feb-11 & 558 & SB6 PS\#4 \\
\hline
\end{tabular}

\subsection{Experimental Procedure}

\subsection{Visual Examination, Extraction and Washing}

Upon arrival at SRNL, each of the pour stream glasses were inspected, and then samples were removed from the $\mathrm{Pt} / \mathrm{Au}$ collection boats and washed according to procedure prior to analysis. ${ }^{8}$

\subsection{Chemical Composition}

A sample of SB6 PS\#3 was ground and then sieved to -200 mesh. Quadruplicate samples of the

\footnotetext{
${ }^{\mathrm{a}}$ MFT Batch 558 and MFT Batch 568A, which will be denoted as MFT-558 and MFT-568A in the text.
} 
pour stream glass were digested by two separate methods: aqua regia (AR $)^{9}$ and sodium peroxide fusion (PF). ${ }^{10}$ Three Analytical Reference Glass (ARG-1) standards were also digested by each method and submitted along with the samples. All of the prepared samples were submitted to Analytical Development (AD) and analyzed by Inductively Coupled Plasma-Atomic Emission Spectroscopy (ICP-AES). A multi-element standard and blank were also included in the analyses in order to assess the performance of the instrument over the course of the analyses.

\subsection{Radionuclide Composition}

The SB6 PS\#3 glass sample was prepared in quadruplicate using peroxide fusion and was analyzed by AD using Inductively Coupled Plasma - Mass Spectroscopy (ICP-MS) to determine actinide and fission product content. The glass was also dissolved by a mixed acid dissolution ${ }^{11}$ and was analyzed by counting methods to calculate the radionuclide concentration. The reportable radionuclides for the Glass Product Control Program not measured in this study were calculated from the slurry results using a calculated Waste Dilution Factor (WDF).

\subsection{Noble Metals}

Noble metal concentrations were analyzed in SB6 PS\#3 using ICP-MS from the peroxide fusion dissolution. The total silver concentration is calculated using the measured concentration of ${ }^{109} \mathrm{Ag}$ and the calculated concentration of ${ }^{107} \mathrm{Ag} .{ }^{12}$ Due to interference from $\mathrm{Cd}$, the palladium concentration is calculated using the sum of the measured concentration of ${ }^{105} \mathrm{Pd}$ and the calculated concentrations of ${ }^{106} \mathrm{Pd},{ }^{107} \mathrm{Pd},{ }^{108} \mathrm{Pd}$, and ${ }^{110} \mathrm{Pd}$ using their fission yields. ${ }^{12}$ The total concentration of ruthenium is calculated from the sum of the measured concentrations of three isotopes: ${ }^{101} \mathrm{Ru},{ }^{102} \mathrm{Ru}$, and ${ }^{104} \mathrm{Ru}$. The reported concentration of rhodium is from the measured concentration of a single isotope, ${ }^{103} \mathrm{Rh}$.

In addition, a sample of SB6 PS\#3 was analyzed using Scanning Electron Microscopy (SEM) along with Energy Dispersive Spectroscopy (EDS) to image and analyze any inhomogeneities, including noble metal inclusions, in the glass. Samples of SB6 PS\#1, \#2 and \#3 were also submitted for X-ray Diffraction (XRD) analysis.

\subsection{Product Consistency Test (PCT)}

The PCT was performed on quadruplicate samples of SB6 PS\#3 to assess chemical durability using Method A of the procedure. ${ }^{13}$ Also included was the Environmental Assessment (EA) glass, the Approved Reference Material (ARM) glass, and blanks from the sample cleaning batch. Samples were ground, washed, and prepared according to the standard procedure. ARM and EA were prepared in triplicate whereas the SB6 PS\#3 sample was prepared in quadruplicate. The resulting solutions were sampled (filtered and acidified) and analyzed by AD. Samples of a multi-element, standard solution were also included with the glass samples as a check on the accuracy of the ICP-AES. Normalized release rates were calculated based on the measured composition using the average ${ }^{\mathrm{b}}$ of the leachate concentrations.

\subsection{Density}

The densities of SB6 PS\#2 and SB6 PS\#4 were measured with a Gay-Lussac pycnometer. ${ }^{\mathrm{c}}$ By using the mass of the empty pycnometer $\left(m_{0}\right)$, pycnometer and sample $\left(m_{l}\right)$, pycnometer and sample and water $\left(m_{2}\right)$ and pycnometer and water $\left(m_{3}\right)$, the density of the sample $\left(\rho_{s}\right)$ is calculated by

\footnotetext{
${ }^{b}$ It should be noted that one of the sets of triplicate values for EA was not used in the calculation due to erroneous results. It appears that a sample of ARM was used instead of EA.

${ }^{\mathrm{c}}$ No glass was available to measure the density of SB6 PS\#3; however measurement of SB6 PS\#2 and \#4 should be bounding.
} 


$$
\rho_{S}=\frac{\rho_{H 2 Q}\left(m_{1}-m_{0}\right)}{\left(m_{3}-m_{0}\right)-\left(m_{2}-m_{1}\right)}
$$

where $\rho_{H 2 O}{ }^{d}$ is the density of water at the measurement temperature. A reference glass ${ }^{\mathrm{e}}$ was included in the set of measurements as an internal check of the measurement technique in the shielded cells.

\section{7 $\underline{\text { REDOX }}$}

\subsubsection{Pour Stream Samples}

A sample of each pour stream glass was ground and then sieved to -200 mesh. All samples were prepared for REDOX measurement and analyzed via UV-Vis spectroscopy according to procedure. $^{14}$ In addition to the pour stream samples, the EA glass was included in each set of measurements as an internal check of the measured REDOX value.

\subsubsection{MFT Samples}

Both of the MFT slurry samples were prepared in triplicate and vitrified via the sealed crucible method according to procedure. ${ }^{15}$ All of the samples were removed from the alumina crucibles, ground and sieved to -200 mesh. The samples were then prepared and analyzed in a similar manner as the pour stream samples (Section 2.7.1).

\subsection{Summary}

A summary of the analyses for each pour stream sample is shown in Table 2-1.

Table 2-1. Summary of SB6 Pour Stream Glass Analyses

\begin{tabular}{|c|l|}
\hline Sample ID & \multicolumn{1}{|c|}{ Analyses } \\
\hline SB6 PS\#1 & REDOX and XRD \\
\hline SB6 PS\#2 & REDOX, XRD, density \\
\hline SB6 PS\#3 & $\begin{array}{l}\text { Chemical composition, radionuclides, noble } \\
\text { metals, PCT, SEM-EDS, REDOX and } \\
\text { XRD }\end{array}$ \\
\hline SB6 PS\#4 & REDOX and density \\
\hline
\end{tabular}

\subsection{Results and Discussion}

\subsection{Visual Examination and Analysis}

Upon the receipt inspection, none of the pour stream glasses appeared to have a significant surface film (if any); however, the surface rinse water ${ }^{\mathrm{f}}$ from SB6 PS\#2 and SB6 PS\#3 did contain a detectable amount of sulfate as shown in Table 3-1. Presence of a sulfate layer, specifically $\mathrm{Na}_{2} \mathrm{SO}_{4}$, was also detected on the surface of the SB5 pour stream glass. ${ }^{16}$

\footnotetext{
d The density of $\mathrm{H}_{2} \mathrm{O}$ was assumed to be $1 \mathrm{~g} / \mathrm{cm}^{3}$ for all measurements.

${ }^{\mathrm{e}}$ The density of a sample of NIST 1830 glass was determined to be $2.49 \mathrm{~g} / \mathrm{cm}^{3}$ using the Archimedes method (ITS0057) prior to its placement in the shielded cells.

${ }^{\mathrm{f}}$ Samples were rinsed with de-ionized water prior to removal from the Pt-Au collection boat and submitted to AD for Ion Chromatography (IC) anion analysis.
} 
SRNL-STI-2011-00555

Revision 0

Table 3-1. Analysis of Glass Surface Rinse Water

\begin{tabular}{|c|c|}
\hline Anion & Concentration $(\boldsymbol{\mu g} \mathbf{/ m L})$ \\
\hline Fluoride & $<10$ \\
\hline Formate & $<10$ \\
\hline Chloride & $<10$ \\
\hline Nitrite & $<10$ \\
\hline Nitrate & 17 \\
\hline Phosphate & $<10$ \\
\hline Sulfate & 161 \\
\hline Oxalate & $<10$ \\
\hline Bromide & $<10$ \\
\hline
\end{tabular}

(a) SB6 PS\#2

\begin{tabular}{|c|c|}
\hline Anion & Concentration $(\boldsymbol{\mu g} \mathbf{m} \mathbf{m})$ \\
\hline Fluoride & 2 \\
\hline Formate & $<1$ \\
\hline Chloride & 4 \\
\hline Nitrite & $<1$ \\
\hline Nitrate & 10 \\
\hline Phosphate & $<1$ \\
\hline Sulfate & 292 \\
\hline Oxalate & $<1$ \\
\hline Bromide & $<1$ \\
\hline
\end{tabular}

(b) SB6 PS\#3

\subsection{Chemical Composition}

Table 5-1 and Table 5-2 in Appendix A provide the measured elemental data from glasses prepared using aqua regia and peroxide fusion, respectively.

\subsubsection{ARG-1}

Table 3-2 shows a comparison of the published ${ }^{17}$ and measured composition of the ARG-1 glass. The measured value is the average of the six replicates (three from each dissolution method) unless otherwise noted. In general, the measured values are consistent with the published values; however, there was some variation in the measurement of $\mathrm{SiO}_{2}$ as shown by the Relative Standard Deviation (\%RSD). The sum of oxides is within the Product Composition Control System (PCCS) acceptance limits (the interval of 95 to $105 \mathrm{wt} \%$ ).

\subsubsection{SB6 PS\#3}

Table 3-3 lists the oxide composition of the SB6 PS\#3 glass. The measured value is the average of the eight replicates (four from each dissolution methods) unless otherwise noted. Some of the analytes were below the detection limit of the instrument and are noted by a result preceded with a " $<$." The $\%$ RSD for the major glass components $(>0.5 \mathrm{wt} \%)$ is less than $10 \%$, indicating good precision in the results.

\subsubsection{WDF}

The WDF for a specific sludge batch is given by

$$
W D F(i)=\frac{\operatorname{CS}(i)}{\operatorname{CG}(0)}
$$

where $C S(i)$ is the concentration of component $i$ in the dried Tank 40 sludge $^{18}$ and $C G(i)$ is the concentration of component $i$ in the corresponding pour stream glass sample. Table 3-4 contains the calculated WDF values for Al, Ca, Fe and Mn for SB6. The average WDF value will be used in Section 3.3 to calculate the concentration of radionuclides that were not directly measured in the glass. 
Table 3-2. Published ${ }^{17}$ and Measured Values of ARG-1

\begin{tabular}{|c|c|c|c|c|}
\hline Oxide & $\begin{array}{c}\text { Published } \\
\text { (wt\%) }\end{array}$ & $\begin{array}{c}\text { Meas ured } \\
\text { (wt\%) }\end{array}$ & \% RSD & $\begin{array}{c}\text { Digestion } \\
\text { Method }\end{array}$ \\
\hline $\mathrm{Al}_{2} \mathrm{O}_{3}$ & 4.73 & 4.48 & 6.5 & PF, AR \\
\hline $\mathrm{B}_{2} \mathrm{O}_{3}$ & 8.67 & 7.92 & 5.4 & PF, AR \\
\hline $\mathrm{BaO}$ & 0.088 & 0.09 & 5.0 & PF, AR \\
\hline $\mathrm{CaO}$ & 1.43 & 1.49 & 3.8 & AR \\
\hline $\mathrm{Cr}_{2} \mathrm{O}_{3}$ & 0.093 & 0.10 & 6.0 & PF, AR \\
\hline $\mathrm{Fe}_{2} \mathrm{O}_{3}$ & 14.0 & 13.96 & 5.5 & PF, AR \\
\hline $\mathrm{K}_{2} \mathrm{O}$ & 2.71 & 2.64 & 3.6 & AR \\
\hline $\mathrm{Li}_{2} \mathrm{O}$ & 3.21 & 3.15 & 4.9 & PF, AR \\
\hline $\mathrm{MgO}$ & 0.86 & 0.85 & 5.0 & PF, AR \\
\hline $\mathrm{MnO}$ & 1.88 & 1.81 & 4.7 & PF, AR \\
\hline $\mathrm{Na}_{2} \mathrm{O}$ & 11.5 & 11.18 & 3.8 & AR \\
\hline $\mathrm{NiO}$ & 1.05 & 1.02 & 4.9 & PF, AR \\
\hline $\mathrm{P}_{2} \mathrm{O}_{5}$ & 0.22 & 0.25 & 9.9 & PF, AR \\
\hline $\mathrm{SiO}$ & 47.9 & 48.21 & 10.7 & PF \\
\hline $\mathrm{TiO}$ & 1.15 & 1.02 & 10.3 & PF, AR \\
\hline $\mathrm{ZnO}$ & 0.02 & 0.02 & 16.1 & PF, AR \\
\hline $\mathrm{ZrO} 2$ & 0.13 & 0.07 & 11.6 & AR \\
\hline $\mathrm{Total}_{2}$ & 99.64 & 98.26 & --- & --- \\
\hline
\end{tabular}

Table 3-3. Average Measured Composition of SB6 PS\#3

\begin{tabular}{|c|c|c|c|}
\hline Oxide & $\begin{array}{c}\text { Measured } \\
\text { (wt\%) }\end{array}$ & \%RSD & $\begin{array}{c}\text { Digestion } \\
\text { Method }\end{array}$ \\
\hline $\mathrm{Al}_{2} \mathrm{O}_{3}$ & 8.63 & 5.7 & PF, AR \\
\hline $\mathrm{B}_{2} \mathrm{O}_{3}$ & 4.55 & 7.3 & PF, AR \\
\hline $\mathrm{BaO}$ & 0.06 & 7.0 & PF, AR \\
\hline $\mathrm{BeO}$ & $<0.001$ & NA & PF, AR \\
\hline $\mathrm{CaO}$ & 0.61 & 4.5 & AR \\
\hline $\mathrm{CdO}$ & 0.01 & 7.8 & PF, AR \\
\hline $\mathrm{Ce}_{2} \mathrm{O}_{3}$ & $<0.08$ & NA & PF, AR \\
\hline $\mathrm{Cr}_{2} \mathrm{O}_{3}$ & 0.16 & 4.3 & PF, AR \\
\hline $\mathrm{CuO}_{2}$ & 0.21 & 5.8 & PF, AR \\
\hline $\mathrm{Fe}_{2} \mathrm{O}_{3}$ & 8.74 & 4.6 & PF, AR \\
\hline $\mathrm{Gd}_{2} \mathrm{O}_{3}$ & 0.04 & 23.4 & PF, AR \\
\hline $\mathrm{K}_{2} \mathrm{O}$ & 0.09 & 1.9 & AR \\
\hline $\mathrm{La}_{2} \mathrm{O}_{3}$ & 0.04 & 8.1 & PF, AR \\
\hline $\mathrm{Li}_{2} \mathrm{O}$ & 4.92 & 5.2 & PF, AR \\
\hline $\mathrm{MgO}_{2} \mathrm{O}$ & 0.33 & 5.4 & PF, AR \\
\hline $\mathrm{MnO}$ & 2.19 & 5.2 & PF, AR \\
\hline
\end{tabular}

\begin{tabular}{|c|c|c|c|}
\hline Oxide & $\begin{array}{c}\text { Meas ured } \\
\text { (wt\%) }\end{array}$ & \%RSD & $\begin{array}{c}\text { Digestion } \\
\text { Method }\end{array}$ \\
\hline $\mathrm{MoO}_{3}$ & $<0.02$ & NA & PF, AR \\
\hline $\mathrm{Na}_{2} \mathrm{O}$ & 14.86 & 5.0 & AR \\
\hline $\mathrm{NiO}$ & 1.02 & 6.6 & PF, AR \\
\hline $\mathrm{P}_{2} \mathrm{O}_{5}$ & $<0.17$ & NA & PF, AR \\
\hline $\mathrm{PbO}$ & $<0.04$ & NA & PF, AR \\
\hline $\mathrm{SO}_{4}$ & $<0.18$ & NA & AR \\
\hline $\mathrm{Sb}_{2} \mathrm{O}_{3}$ & $<0.08$ & NA & PF, AR \\
\hline $\mathrm{SiO}_{2}$ & 49.10 & 5.1 & PF \\
\hline $\mathrm{SnO}_{2}$ & $<0.03$ & NA & PF, AR \\
\hline $\mathrm{SrO}$ & 0.02 & 5.2 & PF, AR \\
\hline $\mathrm{ThO}_{2}$ & 1.00 & 9.9 & PF, AR \\
\hline $\mathrm{TiO}_{2}$ & 0.35 & 4.7 & PF, AR \\
\hline $\mathrm{U}_{3} \mathrm{O}_{8}$ & 1.83 & 5.3 & PF, AR \\
\hline $\mathrm{ZnO}_{2 n}$ & 0.06 & 4.2 & PF, AR \\
\hline $\mathrm{ZrO}_{2}$ & 0.12 & 9.6 & AR \\
\hline $\mathrm{Total}$ & 99.57 & --- & --- \\
\hline
\end{tabular}


Table 3-4. Waste Dilution Factor for SB6 PS\#3

\begin{tabular}{|c|c|c|c|}
\hline \multirow{2}{*}{ Ele me nt } & \multicolumn{2}{|c|}{ Concentration (wt\%) } & \multirow{2}{*}{ WDF } \\
\cline { 2 - 3 } & Drie d Sludge Slurry $^{\mathbf{1 8}}$ & Glass & \\
\hline $\mathrm{Al}$ & 10.6 & 4.57 & 2.3 \\
\hline $\mathrm{Ca}$ & 0.868 & 0.44 & 2.0 \\
\hline $\mathrm{Fe}$ & 14.0 & 6.11 & 2.3 \\
\hline $\mathrm{Mn}$ & 4.30 & 1.70 & 2.5 \\
\hline Average & --- & --- & 2.3 \\
\hline Std. Dev. & --- & --- & 0.2 \\
\hline
\end{tabular}

\subsection{Radionuclide Composition}

Based on measurements and analytical detection limits, thirty radionuclides have been identified as reportable for DWPF SB6 (MB7) as specified by the Waste Acceptance Product Specification (WAPS) 1.2. ${ }^{1, \mathrm{~g}}$ Selected radionuclides were directly measured in quadruplicate either by gamma counting, beta counting, alpha spectroscopy or ICP-MS. Table 5-3 lists the average concentration of these radionuclides in the SB6 pour stream glass. ${ }^{\mathrm{h}}$ Table 5-3 and Table 5-4 in Appendix A provide the actual measured radiological chemical and ICP-MS data, respectively. Some of the analytes were below the detection limit of the instrument and are noted by a result preceded with a " $<$." The content of each radionuclide was also calculated from measured values of the Tank 40 dried SB6 sludge and the average WDF value shown in Table 3-4. ${ }^{1}$

\subsection{Noble Metals}

The average measured concentrations of the noble metals based on quadruplicate measurements of SB6 PS\#3 are listed in Table 3-6. Table 5-4 in Appendix A provides the actual measured ICPMS data. The calculated noble metal concentration in the glass is determined from the concentration in the Tank 40 sludge $^{18}$ and the average WDF value (Table 3-4).

In addition to ICP-MS, the SB6 PS\#3 glass was also analyzed with SEM-EDS for noble metal inclusions. Examination of the glass with EDS indicated the presence of both $\mathrm{Ru}$ and $\mathrm{Pd}$, which corresponds to the results of the ICP-MS noble metals analysis in Table 3-6. ${ }^{\mathrm{i}}$ Noble metal inclusions have been observed in previous pour stream samples, including SB4 and SB5. ${ }^{16}$

$\mathrm{Ru}$ was also detected via XRD in SB6 PS\#1 as shown in Figure 3-1. No crystalline phases were detected in SB6 PS\#2 and \#3.

\footnotetext{
${ }^{\mathrm{g}}$ Th-229 was identified as reportable for SB6; however, there is no direct method for measuring its concentration, so its value will not be presented in this report. Based on the calculated values presented in SRNL-STI-2011-00189, Th-229 becomes reportable in the year 2715, which is of no practical significance to this study.

${ }^{\mathrm{h}} \mathrm{Th}-232$ was also added to the list as it was measured at greater than $0.2 \mathrm{wt} \%$ by ICP-MS.

${ }^{\mathrm{i}}$ More details can be found in notebook SRNL-NB-2011-00029 (pages 74-77).
} 
SRNL-STI-2011-00555

Revision 0

Table 3-5. Reportable Radionuclide Content of the SB6 PS\#3 Glass

\begin{tabular}{|c|c|c|c|}
\hline \multirow[t]{2}{*}{ Radionuclide } & $\begin{array}{c}\text { Tank } 40 \text { SB6 } \\
\text { Dried Sludge }\end{array}$ & $\begin{array}{c}\text { Calculated SB6 } \\
\text { Glass }\end{array}$ & $\begin{array}{c}\text { Me asured SB6 } \\
\text { Glass }\end{array}$ \\
\hline & \multicolumn{3}{|c|}{$(\mathrm{Ci} / \mathbf{k g})$} \\
\hline $\mathrm{Ni}-59$ & $1.1 \mathrm{E}-03$ & 4.6E-04 & --- \\
\hline $\mathrm{Ni}-63$ & $1.1 \mathrm{E}-01$ & 4.7E-02 & --- \\
\hline $\mathrm{Se}-79$ & $9.1 \mathrm{E}-06$ & $4.0 \mathrm{E}-06$ & --- \\
\hline Sr-90 & $1.9 \mathrm{E}+01$ & $8.1 \mathrm{E}+00$ & $5.9 \mathrm{E}+00$ \\
\hline Zr-93 & $4.6 \mathrm{E}-04$ & $2.0 \mathrm{E}-04$ & $5.3 \mathrm{E}-04$ \\
\hline $\mathrm{Nb}-93 \mathrm{~m}$ & $3.8 \mathrm{E}-04$ & $1.6 \mathrm{E}-04$ & --- \\
\hline Tc-99 & $<1.1 \mathrm{E}-04$ & $<2.5 \mathrm{E}-04$ & $<1.3 \mathrm{E}-04$ \\
\hline Sn-121m & $<4.7 \mathrm{E}-03$ & $<2.0 \mathrm{E}-03$ & --- \\
\hline Sn-126 & $<1.5 \mathrm{E}-04$ & $<6.5 \mathrm{E}-05$ & --- \\
\hline Cs-137 & $3.9 \mathrm{E}-01$ & $1.7 \mathrm{E}-01$ & $1.3 \mathrm{E}+00$ \\
\hline Sm-151 & $2.6 \mathrm{E}-01$ & $1.1 \mathrm{E}-01$ & --- \\
\hline Th-232 & $2.4 \mathrm{E}-06$ & $1.1 \mathrm{E}-06$ & $9.3 \mathrm{E}-07$ \\
\hline U-233 & $9.0 \mathrm{E}-05$ & $3.9 \mathrm{E}-05$ & $7.0 \mathrm{E}-05$ \\
\hline U-234 & $8.4 \mathrm{E}-05$ & $3.6 \mathrm{E}-05$ & $4.2 \mathrm{E}-05$ \\
\hline U-235 & $6.0 \mathrm{E}-07$ & $2.6 \mathrm{E}-07$ & $2.3 \mathrm{E}-07$ \\
\hline $\mathrm{U}-236$ & $1.3 \mathrm{E}-06$ & $5.8 \mathrm{E}-07$ & $6.3 \mathrm{E}-07$ \\
\hline U-238 & $1.2 \mathrm{E}-05$ & $5.3 \mathrm{E}-06$ & $5.1 \mathrm{E}-06$ \\
\hline $\mathrm{Np}-237$ & $3.6 \mathrm{E}-05$ & $1.6 \mathrm{E}-05$ & $1.7 \mathrm{E}-05$ \\
\hline $\mathrm{Pu}-238$ & $3.8 \mathrm{E}-01$ & $1.7 \mathrm{E}-01$ & $1.4 \mathrm{E}-01$ \\
\hline $\mathrm{Pu}-239$ & $1.8 \mathrm{E}-02$ & $7.9 \mathrm{E}-03$ & $7.7 \mathrm{E}-03$ \\
\hline $\mathrm{Pu}-240$ & $6.5 \mathrm{E}-03$ & $2.8 \mathrm{E}-03$ & $2.9 \mathrm{E}-03$ \\
\hline $\mathrm{Pu}-241$ & $<8.3 \mathrm{E}-02$ & $<3.6 \mathrm{E}-02$ & $3.7 \mathrm{E}-02$ \\
\hline $\mathrm{Pu}-242$ & $<1.5 \mathrm{E}-05$ & $<6.5 \mathrm{E}-06$ & $<1.4 \mathrm{E}-05$ \\
\hline Am-241 & $3.3 \mathrm{E}-02$ & $1.4 \mathrm{E}-02$ & $1.4 \mathrm{E}-02$ \\
\hline Am-242m & $2.3 \mathrm{E}-04$ & $9.8 \mathrm{E}-05$ & --- \\
\hline Am-243 & $4.3 \mathrm{E}-03$ & $1.9 \mathrm{E}-03$ & --- \\
\hline $\mathrm{Cm}-244$ & $1.5 \mathrm{E}-01$ & $6.5 \mathrm{E}-02$ & --- \\
\hline $\mathrm{Cm}-245$ & $2.0 \mathrm{E}-05$ & $8.9 \mathrm{E}-06$ & --- \\
\hline Cm-246 & $6.5 \mathrm{E}-05$ & $2.8 \mathrm{E}-05$ & --- \\
\hline Cm-248 & $<7.1 \mathrm{E}-06$ & $<3.1 \mathrm{E}-06$ & --- \\
\hline Cf-249 & $<2.3 \mathrm{E}-05$ & $<1.0 \mathrm{E}-05$ & --- \\
\hline Cf-251 & $<5.5 \mathrm{E}-05$ & $<2.4 \mathrm{E}-05$ & --- \\
\hline $\begin{array}{l}\text { Alpha Sp } \\
\text { Beta Cou } \\
\text { Gamma C }\end{array}$ & $\begin{array}{l}\text { ectroscopy: } \\
\text { nting: } \\
\text { 'ounting: }\end{array}$ & $\begin{array}{l}\mathrm{Pu}-238 \\
\mathrm{Sr}-90 \text { and } \mathrm{Pu}-241 \\
\mathrm{Cs}-137 \text { and } \mathrm{Am}-241 \\
\mathrm{Zr}-93, \mathrm{Tc}-99, \mathrm{Th}-232, \mathrm{~L} \\
\mathrm{U}-235, \mathrm{U}-236, \mathrm{U}-238 \\
\text { 239, } \mathrm{Pu}-240 \text { and } \mathrm{Pu}-242\end{array}$ & $\begin{array}{l}\text {-233, U-234, } \\
\text { Jp-237, Pu- }\end{array}$ \\
\hline
\end{tabular}


SRNL-STI-2011-00555

Revision 0

Table 3-6. Noble Metal Concentration in the SB6 PS\#3 Glass

\begin{tabular}{|c|c|c|c|}
\hline \multirow{2}{*}{ Noble Metal } & $\begin{array}{c}\text { Tank 40 SB6 } \\
\text { Dried Sludge }^{\mathbf{1 8}}\end{array}$ & $\begin{array}{c}\text { Calculated SB6 } \\
\text { Glass }\end{array}$ & $\begin{array}{c}\text { Measured SB6 } \\
\text { Glass }\end{array}$ \\
\cline { 2 - 4 } & \multicolumn{3}{|c|}{$\mathbf{( w t \% )}$} \\
\hline $\mathrm{Ag}$ & 0.01 & 0.006 & 0.008 \\
\hline $\mathrm{Pd}$ & 0.003 & 0.001 & 0.002 \\
\hline $\mathrm{Rh}$ & 0.02 & 0.009 & 0.01 \\
\hline $\mathrm{Ru}$ & 0.09 & 0.04 & 0.05 \\
\hline
\end{tabular}

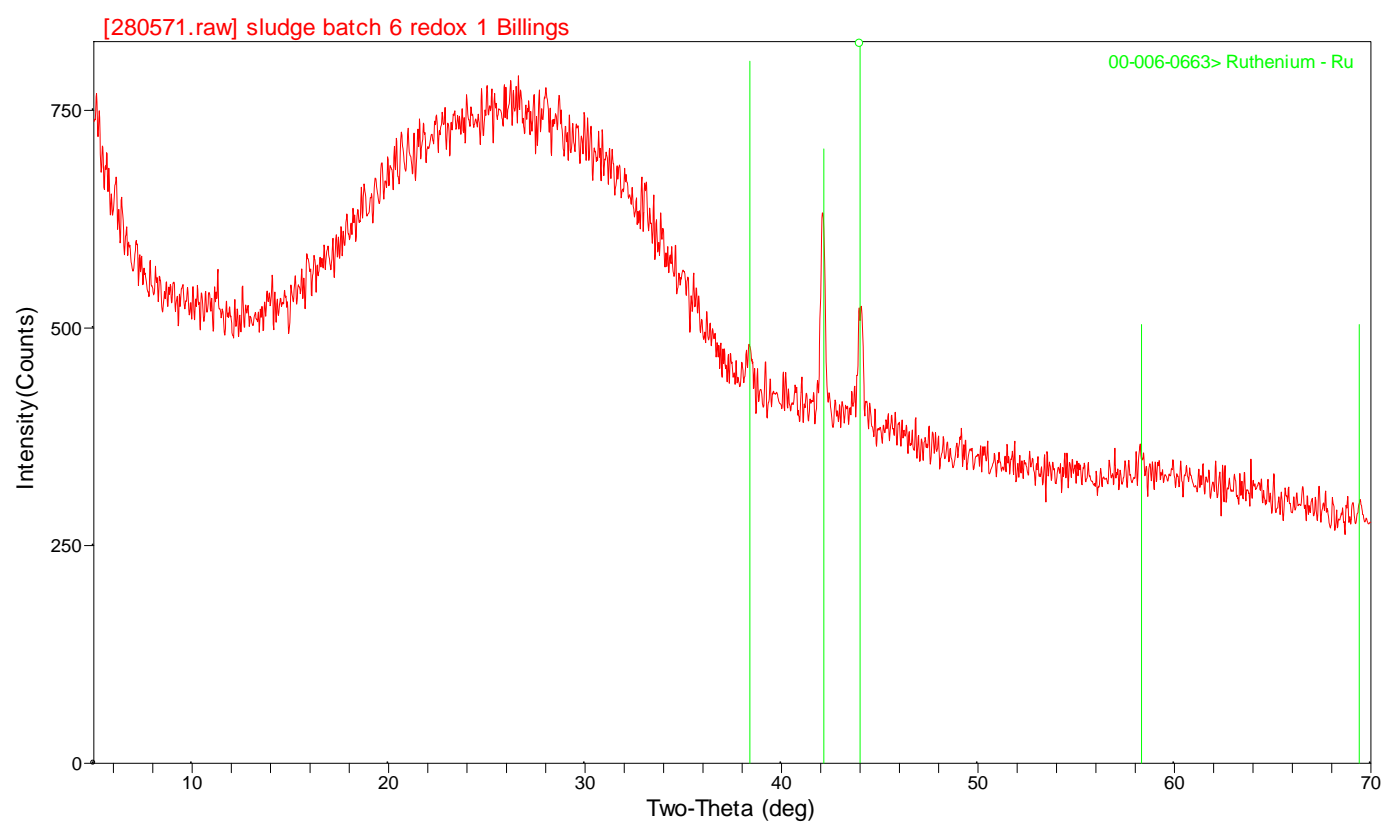

Figure 3-1. XRD spectrum of SB6 PS\#1.

\subsection{PCT}

The average normalized release values for $\mathrm{ARM}^{\mathrm{j}}$, EA and SB6 PS\#3 are shown in Table 3-7. 19,20 No water loss issues were observed over the course of the test. Table 5-5 in Appendix A provides the elemental leachate concentrations for the solution samples generated by the PCTs. The normalized release values of the pour stream glass for $\mathrm{B}, \mathrm{Li}, \mathrm{Na}$ and $\mathrm{Si}$ are below $1 \mathrm{~g} / \mathrm{L}$, which is very acceptable with respect to the EA glass benchmark value of $16.7 \mathrm{~g} / \mathrm{L}$.

\subsection{Density}

The densities of SB6 PS\#2 and \#4 were determined to be $2.6 \mathrm{~g} / \mathrm{cm}^{3}$ and $2.5 \mathrm{~g} / \mathrm{cm}^{3}$, respectively. Data from the density measurements are shown in Table 5-6 in Appendix A.

\subsection{REDOX}

Summaries of the REDOX results of the pour stream samples and vitrified MFT samples were

\footnotetext{
${ }^{\mathrm{j}}$ The concentrations of each element of interest for ARM are within the control limits stated in THERMO ${ }^{\mathrm{TM}}$.
} 
communicated to DWPF in a series of brief memoranda. ${ }^{21-23}$ Table 3-8 and Table 3-9 list the average calculated values for $\mathrm{Fe}^{2+} / \sum \mathrm{Fe}$ and $\mathrm{Fe}^{2+} / \mathrm{Fe}^{3+}$ for the pour stream samples and MFT samples, respectively. Complete sets of data for each of the replicates and EA samples included with individual sets are shown in Table 5-7 and Table 5-8 in Appendix A.

Table 3-7. Normalized PCT Results for SB6 PS\#3 (g/L)

\begin{tabular}{|c|c|c|c|c|}
\hline Glass ID & NL B & NL Li & NL Na & NL Si \\
\hline ARM & 0.46 & 0.54 & 0.48 & 0.27 \\
\hline St. Dev. & 0.004 & 0.004 & 0.003 & 0.002 \\
\hline \% RSD & 0.8 & 0.7 & 0.6 & 0.6 \\
\hline EA & 16.60 & 9.56 & 13.36 & 3.96 \\
\hline St. Dev. & 0.02 & 0.04 & 0 & 0 \\
\hline \% RSD & 0.1 & 0.4 & 0 & 0 \\
\hline SB6 PS\#3 & 0.69 & 0.81 & 0.85 & 0.49 \\
\hline St. Dev. & 0.02 & 0.01 & 0.02 & 0.01 \\
\hline \% RSD & 2.5 & 1.6 & 2.8 & 2.8 \\
\hline
\end{tabular}

Table 3-8. SB6 Pour Stream Glass REDOX Data

\begin{tabular}{|c|c|c|}
\hline Sample ID & $\mathbf{F e}^{2+} / \sum \mathbf{F e}$ & $\mathbf{F e}^{\mathbf{2 +}} / \mathbf{F e}^{\mathbf{3 +}}$ \\
\hline SB6 PS\#1 & 0.25 & 0.34 \\
\hline SB6 PS\#2 & 0.32 & 0.47 \\
\hline SB6 PS\#3 & 0.38 & 0.60 \\
\hline SB6 PS\#4 & 0.41 & 0.69 \\
\hline
\end{tabular}

Table 3-9. SB6 MFT Glass REDOX Data ${ }^{k}$

\begin{tabular}{|c|c|c|}
\hline Sample ID & $\mathbf{F e}^{2+} / \sum \mathbf{F e}$ & $\mathbf{F e}^{2+} / \mathbf{F e}^{\mathbf{3 +}}$ \\
\hline MFT-558-1 & 0.50 & 1.00 \\
\hline MFT-558-2 & 0.44 & 0.81 \\
\hline SB6 MFT 568A-A & 0.16 & 0.20 \\
\hline SB6 MFT 568A-B & 0.06 & 0.06 \\
\hline SB6 MFT 568A-C & 0.02 & 0.03 \\
\hline
\end{tabular}

\footnotetext{
${ }^{\mathrm{k}}$ Due to time restraints only two of the three samples were prepared for REDOX measurements.
} 


\subsection{Conclusions}

- The sum of oxides for the official SB6 pour stream glass is within the PCCS limits (95$105 \mathrm{wt} \%)$.

- The average calculated WDF for SB6 is 2.3. In general, the measured radionuclide content of the official SB6 pour stream glass is in good agreement with the calculated values from the Tank 40 dried sludge results from the SB6 WAPS sample; however, the measured value of Cs-137 is an order of magnitude higher than calculated, which is expected since the Tank 40 sample does not account for salt addition.

- As in previous pour stream samples, ruthenium and palladium inclusions were detected by SEM-EDS in the official SB6 pour stream sample.

- The PCT results indicate that the official SB6 pour stream glass meets the waste acceptance criteria for durability with a normalized boron release of $0.69 \mathrm{~g} / \mathrm{L}$, which is an order of magnitude less than the EA glass.

- The measured density of the SB6 pour stream glass was in the range of $2.5-2.6 \mathrm{~g} / \mathrm{cm}^{3}$.

- The $\mathrm{Fe}^{2+} / \sum \mathrm{Fe}$ ratio of the SB6 pour stream samples were in the range of $0.25-0.41$, while the MFT-558 sample was in the range of $0.44-0.50$ and the MFT-568A sample was in the range of $0.02-0.16$.

\subsection{References}

1. C.J. Bannochie and D.P. DiPrete, "Determination of Reportable Radionuclides for DWPF Sludge Batch 6 (Macrobatch 7)," Savannah River National Laboratory, Aiken, SC, SRNL-STI-2011-00189, 2011.

2. $\quad$ K.M. Fox and T.B. Edwards, "Glass Frit Composition for Sludge Batch 6 Vitrification at the Defense Waste Processing Facility," Savannah River National Laboratory, Aiken, SC, SRNL-L3100-2010-00043, 2010.

3. K.M. Fox, T.B. Edwards, and J.R. Zamecnik, "Frit Development for Sludge Batch 6," Savannah River National Laboratory, Aiken, SC, SRNL-STI-2010-00137, 2010.

4. J.W. Ray, B.H. Culbertson, S.L. Marra, and M.J. Plodinec, "DWPF Glass Product Control Program," Washington Savannah River Company, Aiken, SC, WSRC-IM-91116-6, Rev. 7, 2007.

5. T.L. Fellinger, "Analysis of Sludge Batch 6 and 7 Pour Stream Samples," Savannah River Remediation, Aiken, SC, HLW-DWPF-TTR-2010-0047, 2010.

6. J.W. Amoroso and A.L. Billings, "Task Technical and Quality Assurance Plan for Analysis of Sludge Batch 6 and 7 Pour Stream Samples and Melter Feed Tank (MFT) Slurry Samples," Savannah River National Laboratory, Aiken, SC, SRNL-RP-201100104, 2011. 
7. J.W. Amoroso and A.L. Billings, "Analytical Study Plan for Analysis of Sludge Batch 6 and 7 Pour Stream Samples and Melter Feed Tank (MFT) Slurry Samples," Savannah River National Laboratory, Aiken, SC, SRNL-RP-2011-00105, 2011.

8. C.J. Bannochie and N.E. Bibler, "Current and New Controls in the Shielded Cells for Handling DWPF Pour Stream Glasses and Comments Concerning S02244 and S02247 Glasses," Savannah River National Laboratory, Aiken, SC, SRNL-ITS-2005-00127, 2005.

9. “Aqua Regia Dissolution of Sludge for Elemental Analysis," Savannah River National Laboratory, Aiken, SC ADS-2226, Latest Revision.

10. "Alkali Fusion Dissolutions of Sludge and Glass for Elemental and Anion Analysis," Savannah River National Laboratory, Aiken, SC, ADS-2502, Latest Revision.

11. "Acid Dissolution of Glass and Sludge for Elemental Analysis," Savannah River National Laboratory, Aiken, SC, ADS-2227, Latest Revision.

12. N.E. Bibler, "Measuring and Predicting Fission Product Noble Metals in Savannah River Site High Level Waste Sludges," Westinghouse Savannah River Company, Aiken, SC, WSRC-TR-2005-0098, 2005.

13. "Standard Test Methods for Determining Chemical Durability of Nuclear, Hazardous, and Mixed Waste Glasses and Multiphase Glass Ceramics: The Product Consistency Test (PCT)," ASTM International, West Conshohocken, PA, ASTM C 1285-02, 2002.

14. "Determining $\mathrm{Fe}^{2+} / \mathrm{Fe}^{3+}$ and $\mathrm{Fe}^{2+} / \mathrm{Fe}$ (Total) Using UV VIS Spectrometer," Savannah River National Laboratory, Aiken, SC, ITS-0042, Latest Revision.

15. "Heat Treatment of Waste Slurries for REDOX $\left(\mathrm{Fe}^{2+} / \mathrm{Fe}\right.$ Total) and Chemical Composition Measurement," Savannah River National Laboratory, Aiken, SC, ITS-0052, Latest Revision.

16. M.M. Reigel and N.E. Bibler, "Analysis of Sludge Batch 4 (Macrobatch 5) for Canister S02902 and Sludge Batch 5 (Macrobatch 6) for Canister S03317 DWPF Pour Stream Glass Samples," Savannah River National Laboratory, Aiken, SC SRNL-STI-201000435, 2010.

17. G.L. Smith, "Characterization of Analytical Reference Glass-1 (ARG-1)," Pacific Northwest National Laboratory, Richland, WA, PNL-8992, 1993.

18. C.J. Bannochie, "Tank 40 Final SB6 Chemical Characterization Results," Savannah River National Laboratory, Aiken, SC, SRNL-STI-2010-00441, 2010.

19. C.M. Jantzen, N.E. Bibler, D.C. Beam, C.L. Crawford, and M.A. Pickett, "Characterization of the Defense Waste Processing Facility (DWPF) Environmental Assessment (EA) Glass Standard Reference Material," Westinghouse Savannah River Company, Aiken, SC, WSRC-TR-92-346, Rev. 1, 1993.

20. C.M. Jantzen, J.B. Pickett, K.G. Brown, T.B. Edwards, and D.C. Beam, "Process/Product Models for the Defense Waste Processing Facility (DWPF): Part I. Predicting Glass Durability from Composition Using a Thermodynamic Hydration Energy Reaction 
Model (THERMO)," Westinghouse Savannah River Company, Aiken, SC, WSRC-TR93-672, Rev. 1, 1995.

21. A.L. Billings, M.M. Reigel, and D.R. Click, "REDOX Analysis of SB4, SB5, and SB6 Pour Stream Glass Samples," Savannah River National Laboratory, Aiken, SC, SRNLL3100-2011-00007, 2011.

22. F.C. Johnson, "REDOX Analysis of a Melter Feed Tank Batch 568a Sample," Savannah River National Laboratory, Aiken, SC, SRNL-L3100-2011-00140, 2011.

23. F.C. Johnson and D.R. Click, "REDOX Analysis of a SB6 Pour Stream Sample and Melter Feed Tank Batch 558 Sample," Savannah River National Laboratory, Aiken, SC, SRNL-L3100-2011-00092, 2011. 
SRNL-STI-2011-00555

Revision 0

Appendix A. Supplemental Data Tables 


\section{Table 5-1. Measured Elemental Concentrations $(\mu \mathrm{g} / \mathrm{g})$ for Glasses Prepared Using an Aqua Regia Dissolution}

\begin{tabular}{|c|c|c|c|c|c|c|c|c|c|c|c|c|c|c|c|c|c|}
\hline Replicate & Glass ID & Lab ID & Al & B & $\mathbf{B a}$ & Be & Ca & Cd & $\mathrm{Ce}$ & $\mathrm{Cr}$ & $\mathrm{Cu}$ & $\mathrm{Fe}$ & Gd & $\mathbf{K}$ & $\mathbf{L a}$ & $\mathbf{L i}$ & Mg \\
\hline 1 & \multirow{3}{*}{ ARG } & 300294848 & 22500 & 24700 & 796 & 23.1 & 10400 & $<24.7$ & $<48$ & 632 & $<50.2$ & 93800 & $<17.1$ & 22200 & $<43$ & 14900 & 5130 \\
\hline 2 & & 300294850 & 22500 & 24700 & 806 & 23.9 & 10400 & $<23.9$ & $<46.6$ & 643 & $<48.6$ & 93400 & $<16.6$ & 22500 & $<41.7$ & 15100 & 5220 \\
\hline 3 & & 300294852 & 24200 & 26200 & 756 & 24.6 & 11100 & $<24.6$ & $<47.9$ & 611 & $<50$ & 99300 & $<17.1$ & 21000 & $<42.9$ & 14200 & 4880 \\
\hline 1 & \multirow{4}{*}{ SB6 PS\#3 } & 300294847 & 47300 & 14800 & 560 & $<4.6$ & 4370 & 117 & 674 & 1150 & 1820 & 61700 & 415 & 786 & 374 & 24200 & 2110 \\
\hline 2 & & 300294849 & 50100 & 15900 & 502 & $<4.86$ & 4610 & 110 & 633 & 1070 & 1650 & 65700 & 381 & 809 & 349 & 22700 & 1990 \\
\hline 3 & & 300294851 & 44700 & 14300 & 494 & $<4.78$ & 4140 & 107 & 612 & 1050 & 1610 & 58700 & 380 & 784 & 340 & 22300 & 1940 \\
\hline 4 & & 300294853 & 45800 & 14600 & 538 & $<4.86$ & 4280 & 115 & 682 & 1140 & 1750 & 60300 & 409 & 773 & 371 & 24300 & 2120 \\
\hline 1 & Blank & 300294846 & $<40$ & $<30$ & $<0.48$ & $<0.48$ & $<32$ & $<24.8$ & $<48.2$ & $<8.16$ & $<5.04$ & $<40$ & $<17.2$ & $<241$ & $<4.32$ & $<11.7$ & $<6$ \\
\hline
\end{tabular}

\begin{tabular}{|c|c|c|c|c|c|c|c|c|c|c|c|c|c|c|c|c|c|}
\hline Replicate & Glass ID & Lab ID & Mn & Mo & $\mathbf{N a}$ & $\mathbf{N i}$ & $\mathbf{P}$ & $\mathbf{P b}$ & $\mathbf{S}$ & $\mathbf{S b}$ & Sn & $\mathbf{S r}$ & Th & $\mathbf{T i}$ & $\mathbf{U}$ & $\mathbf{Z n}$ & $\mathbf{Z r}$ \\
\hline 1 & \multirow{3}{*}{ ARG } & 300294848 & 13700 & $<21.4$ & 81000 & 7940 & 1080 & $<57.1$ & $<598$ & $<425$ & $<89.4$ & 29.8 & $<214$ & 5400 & $<6380$ & 170 & 556 \\
\hline 2 & & 300294850 & 13700 & $<20.7$ & 81300 & 7970 & 1010 & $<55.3$ & $<579$ & $<412$ & $<86.6$ & 30.3 & $<207$ & 5680 & $<6180$ & 173 & 454 \\
\hline 3 & & 300294852 & 14500 & $<21.3$ & 86600 & 8460 & 1010 & $<56.8$ & $<595$ & $<423$ & $<89$ & 28.4 & $<213$ & 5650 & $<6360$ & 160 & 562 \\
\hline 1 & \multirow{4}{*}{ SB6 PS\#3 } & 300294847 & 17400 & 44.2 & 110000 & 8320 & 652 & 161 & $<575$ & $<409$ & $<86$ & 222 & 9830 & 2220 & 15500 & 524 & 766 \\
\hline 2 & & 300294849 & 18500 & 41.5 & 118000 & 8910 & 749 & 143 & $<607$ & $<432$ & $<90.8$ & 208 & 9220 & 2090 & 16700 & 489 & 930 \\
\hline 3 & & 300294851 & 16600 & 33.9 & 105000 & 7960 & 708 & 132 & $<598$ & $<425$ & $<89.4$ & 204 & 9040 & 2050 & 15100 & 475 & 851 \\
\hline 4 & & 300294853 & 17000 & 49.2 & 108000 & 8230 & 788 & 145 & $<607$ & $<432$ & $<90.8$ & 222 & 9800 & 2230 & 15100 & 513 & 949 \\
\hline 1 & Blank & 300294846 & $<4.24$ & $<21.4$ & $<265$ & $<36.4$ & $<69.3$ & $<57.3$ & $<600$ & $<427$ & $<44.9$ & $<0.4$ & $<21.4$ & $<3.04$ & $<641$ & $<7.2$ & $<4.4$ \\
\hline
\end{tabular}


Table 5-2. Measured Elemental Concentrations $(\mu \mathrm{g} / \mathrm{g})$ for Glasses Prepared Using a Peroxide Fusion Dissolution

\begin{tabular}{|c|c|c|c|c|c|c|c|c|c|c|c|c|c|c|c|c|}
\hline Replicate & Glass ID & Lab ID & Al & B & $\mathbf{B a}$ & $\mathbf{B e}$ & $\mathrm{Ca}$ & Cd & $\mathrm{Ce}$ & $\mathrm{Cr}$ & $\mathrm{Cu}$ & $\mathbf{F e}$ & Gd & $\mathbf{K}$ & $\mathbf{L a}$ & $\mathbf{L i}$ \\
\hline 1 & \multirow{3}{*}{ ARG } & 300294829 & 25200 & 24600 & 802 & 25.1 & 12100 & $<24.3$ & $<666$ & 675 & 80.8 & 101000 & $<169$ & 23500 & $<42.4$ & 15100 \\
\hline 2 & & 300294831 & 22100 & 22200 & 727 & 23.7 & 11100 & $<25.3$ & $<693$ & 624 & $<51.4$ & 92500 & $<176$ & 20800 & $<44.1$ & 13400 \\
\hline 3 & & 300294833 & 25700 & 25200 & 838 & 25.4 & 12900 & $<29.1$ & $<797$ & 717 & $<59.2$ & 106000 & $<202$ & 24600 & $<50.7$ & 15200 \\
\hline 1 & \multirow{4}{*}{ SB6 PS\#3 } & 300294828 & 42500 & 12800 & 461 & $<4.58$ & 5550 & 99.2 & $<648$ & 1050 & 1580 & 57900 & 273 & $<2300$ & 320 & 21700 \\
\hline 2 & & 300294830 & 47600 & 14300 & 521 & $<4.58$ & 5990 & 101 & $<648$ & 1170 & 1750 & 64700 & 291 & $<2300$ & 364 & 24000 \\
\hline 3 & & 300294832 & 44700 & 13500 & 491 & $<4.49$ & 5180 & 95.9 & $<636$ & 1090 & 1590 & 61200 & 250 & $<2250$ & 300 & 22300 \\
\hline 4 & & 300294834 & 42500 & 12900 & 460 & $<4.51$ & 5030 & 97 & $<638$ & 1070 & 1560 & 58800 & 223 & $<2260$ & 315 & 21200 \\
\hline 1 & Blank & 300294827 & 330 & $<162$ & $<41.6$ & $<4.8$ & 2070 & $<24.8$ & $<679$ & $<81.6$ & $<50.4$ & 210 & $<172$ & $<2410$ & $<43.2$ & $<117$ \\
\hline
\end{tabular}

\begin{tabular}{|c|c|c|c|c|c|c|c|c|c|c|c|c|c|c|c|c|c|}
\hline Replicate & Glass ID & Lab ID & Mg & Mn & Mo & $\mathbf{N i}$ & $\mathbf{P}$ & $\mathbf{P b}$ & $\mathbf{S}$ & Sb & $\mathbf{S i}$ & Sn & $\mathrm{Sr}$ & Th & $\mathbf{T i}$ & $\mathbf{U}$ & $\mathbf{Z n}$ \\
\hline 1 & \multirow{3}{*}{$\mathrm{ARG}$} & 300294829 & 5290 & 14300 & $<176$ & 8090 & 1230 & $<562$ & $<5880$ & $<1000$ & 235000 & $<440$ & 46.3 & $<210$ & 6750 & $<6340$ & 176 \\
\hline 2 & & 300294831 & 4800 & 13000 & $<184$ & 7360 & 1040 & $<584$ & $<6120$ & $<1040$ & 198000 & $<458$ & 43.3 & $<219$ & 6110 & $<6600$ & 166 \\
\hline 3 & & 300294833 & 5490 & 14800 & $<211$ & 8390 & 1250 & $<672$ & $<7040$ & $<1200$ & 243000 & $<527$ & 51.6 & $<252$ & 6920 & $<7590$ & 239 \\
\hline 1 & \multirow{4}{*}{ SB6 PS\#3 } & 300294828 & 1870 & 15900 & $<172$ & 7250 & $<661$ & $<547$ & $<5730$ & $<975$ & 219000 & $<428$ & 204 & 8060 & 2000 & 15500 & 471 \\
\hline 2 & & 300294830 & 2090 & 17700 & $<172$ & 8140 & 904 & $<547$ & $<5730$ & $<975$ & 245000 & $<428$ & 225 & 8900 & 2220 & 16800 & 527 \\
\hline 3 & & 300294832 & 1930 & 16700 & $<169$ & 7900 & $<649$ & $<536$ & $<5620$ & $<957$ & 232000 & $<420$ & 205 & 7800 & 2080 & 14900 & 506 \\
\hline 4 & & 300294834 & 1850 & 16000 & $<169$ & 7400 & 720 & $<538$ & $<5640$ & $<960$ & 222000 & $<422$ & 195 & 7610 & 1990 & 14500 & 493 \\
\hline 1 & Blank & 300294827 & $<24$ & $<42.4$ & $<180$ & $<364$ & $<693$ & $<573$ & $<6000$ & $<1020$ & $<782$ & $<449$ & $<32$ & $<214$ & $<30.4$ & $<6470$ & $<73.6$ \\
\hline
\end{tabular}


Table 5-3. Measured Radionuclide Concentrations (dpm/g) via Gamma and Beta Counting and Alpha Spectroscopy

\begin{tabular}{|c|c|c|c|c|c|c|c|}
\hline Replicate & Glass s ID & Lab ID & Am-241 & Cs-137 & Pu-238 & Pu-241 & Sr-90 \\
\hline 1 & \multirow{3}{*}{ SB6 P S\#3 } & 300289390 & $3.14 \mathrm{E}+07$ & $2.85 \mathrm{E}+09$ & $3.04 \mathrm{E}+08$ & $7.17 \mathrm{E}+07$ & $1.27 \mathrm{E}+10$ \\
\cline { 4 - 8 } & & 300289391 & $3.07 \mathrm{E}+07$ & $2.95 \mathrm{E}+09$ & $3.16 \mathrm{E}+08$ & $8.09 \mathrm{E}+07$ & $1.35 \mathrm{E}+10$ \\
\cline { 3 - 8 } & 300289392 & $2.89 \mathrm{E}+07$ & $3.01 \mathrm{E}+09$ & $3.27 \mathrm{E}+08$ & $8.71 \mathrm{E}+07$ & $1.51 \mathrm{E}+10$ \\
\cline { 3 - 8 } & & 300289393 & $3.13 \mathrm{E}+07$ & $2.92 \mathrm{E}+09$ & $3.27 \mathrm{E}+08$ & $8.46 \mathrm{E}+07$ & $1.11 \mathrm{E}+10$ \\
\hline 4 & Blank & 300289389 & $<1.82 \mathrm{E}+04$ & $<2.86 \mathrm{E}+06$ & $<3.20 \mathrm{E}+05$ & $<6.46 \mathrm{E}+04$ & $3.47 \mathrm{E}+07$ \\
\hline 1
\end{tabular}


Table 5-4. Measured Concentrations of $\mathrm{m} / \mathrm{z}(\mu \mathrm{g} / \mathrm{g})$ via ICP-MS

\begin{tabular}{|c|c|c|c|c|c|c|c|c|c|}
\hline \multirow{2}{*}{ Replicate } & \multirow{2}{*}{ Glass ID } & \multirow{2}{*}{ Lab ID } & \multicolumn{7}{|c|}{$\mathbf{m} / \mathbf{z}$} \\
\cline { 4 - 10 } & & $\mathbf{9 3}$ & $\mathbf{9 9}$ & $\mathbf{1 0 1}$ & $\mathbf{1 0 2}$ & $\mathbf{1 0 3}$ & $\mathbf{1 0 4}$ & $\mathbf{1 0 5}$ \\
\hline 1 & \multirow{3}{*}{ SB6 PS\#3 } & 300294837 & $2.12 \mathrm{E}+02$ & $<7.63 \mathrm{E}+00$ & $1.96 \mathrm{E}+02$ & $1.83 \mathrm{E}+02$ & $9.78 \mathrm{E}+01$ & $9.48 \mathrm{E}+01$ & $1.40 \mathrm{E}+01$ \\
\cline { 4 - 10 } & 300294838 & $2.20 \mathrm{E}+02$ & $<7.63 \mathrm{E}+00$ & $2.09 \mathrm{E}+02$ & $1.98 \mathrm{E}+02$ & $1.02 \mathrm{E}+02$ & $1.06 \mathrm{E}+02$ & $1.71 \mathrm{E}+01$ \\
\hline & 300294839 & $2.05 \mathrm{E}+02$ & $<7.49 \mathrm{E}+00$ & $1.83 \mathrm{E}+02$ & $1.69 \mathrm{E}+02$ & $8.81 \mathrm{E}+01$ & $8.36 \mathrm{E}+01$ & $1.16 \mathrm{E}+01$ \\
\hline & & 300294840 & $2.06 \mathrm{E}+02$ & $<7.52 \mathrm{E}+00$ & $1.99 \mathrm{E}+02$ & $1.77 \mathrm{E}+02$ & $9.75 \mathrm{E}+01$ & $1.02 \mathrm{E}+02$ & $1.43 \mathrm{E}+01$ \\
\hline 4 & Blank & 300294836 & $1.43 \mathrm{E}+01$ & $<8.00 \mathrm{E}+00$ & $<4.00 \mathrm{E}+00$ & $<4.00 \mathrm{E}+00$ & $<4.00 \mathrm{E}+00$ & $<4.00 \mathrm{E}+00$ & $<1.00 \mathrm{E}+01$ \\
\hline 1 & & 7
\end{tabular}

\begin{tabular}{|c|c|c|c|c|c|c|c|c|c|}
\hline \multirow{2}{*}{ Replicate } & \multirow{2}{*}{ Glass ID } & \multirow{2}{*}{ Lab ID } & \multicolumn{7}{|c|}{$\mathbf{m} / \mathbf{z}$} \\
\hline & & & 106 & 107 & 108 & 109 & 110 & 232 & 233 \\
\hline 1 & \multirow{4}{*}{ SB6 PS\#3 } & 300294837 & $9.35 \mathrm{E}+01$ & $5.36 \mathrm{E}+01$ & $2.98 \mathrm{E}+01$ & $3.08 \mathrm{E}+01$ & $4.01 \mathrm{E}+01$ & $8.96 \mathrm{E}+03$ & $8.19 \mathrm{E}+00$ \\
\hline 2 & & 300294838 & $8.39 \mathrm{E}+01$ & $4.98 \mathrm{E}+01$ & $2.62 \mathrm{E}+01$ & $2.95 \mathrm{E}+01$ & $3.60 \mathrm{E}+01$ & $8.93 \mathrm{E}+03$ & $6.69 \mathrm{E}+00$ \\
\hline 3 & & 300294839 & $7.49 \mathrm{E}+01$ & $4.78 \mathrm{E}+01$ & $2.34 \mathrm{E}+01$ & $2.81 \mathrm{E}+01$ & $3.43 \mathrm{E}+01$ & $7.80 \mathrm{E}+03$ & $6.22 \mathrm{E}+00$ \\
\hline 4 & & 300294840 & $1.04 \mathrm{E}+02$ & $5.63 \mathrm{E}+01$ & $3.41 \mathrm{E}+01$ & $2.58 \mathrm{E}+01$ & $4.39 \mathrm{E}+01$ & $8.36 \mathrm{E}+03$ & $7.92 \mathrm{E}+00$ \\
\hline 1 & Blank & 300294836 & $2.05 \mathrm{E}+02$ & $6.58 \mathrm{E}+01$ & $7.01 \mathrm{E}+01$ & $<6.00 \mathrm{E}+00$ & $8.36 \mathrm{E}+01$ & $5.54 \mathrm{E}+00$ & $<4.00 \mathrm{E}+00$ \\
\hline
\end{tabular}

\begin{tabular}{|c|c|c|c|c|c|c|c|c|c|c|}
\hline \multirow{2}{*}{ Replicate } & \multirow{2}{*}{ Glass ID } & \multirow{2}{*}{ Lab ID } & \multicolumn{8}{|c|}{$\mathbf{m} / \mathbf{z}$} \\
\hline & & & 234 & 235 & 236 & 237 & 238 & 239 & 240 & 242 \\
\hline 1 & \multirow{4}{*}{ SB6 PS\#3 } & 300294837 & $7.44 \mathrm{E}+00$ & $1.13 \mathrm{E}+02$ & $7.62 \mathrm{E}+00$ & $2.29 \mathrm{E}+01$ & $1.65 \mathrm{E}+04$ & $1.33 \mathrm{E}+02$ & $1.18 \mathrm{E}+01$ & $<3.82 \mathrm{E}+00$ \\
\hline 2 & & 300294838 & $6.63 \mathrm{E}+00$ & $1.06 \mathrm{E}+02$ & $1.03 \mathrm{E}+01$ & $2.11 \mathrm{E}+01$ & $1.55 \mathrm{E}+04$ & $1.27 \mathrm{E}+02$ & $1.45 \mathrm{E}+01$ & $<3.82 \mathrm{E}+00$ \\
\hline 3 & & 300294839 & $6.71 \mathrm{E}+00$ & $1.03 \mathrm{E}+02$ & $1.08 \mathrm{E}+01$ & $2.26 \mathrm{E}+01$ & $1.44 \mathrm{E}+04$ & $1.13 \mathrm{E}+02$ & $1.19 \mathrm{E}+01$ & $<3.75 \mathrm{E}+00$ \\
\hline 4 & & 300294840 & $5.84 \mathrm{E}+00$ & $9.62 \mathrm{E}+01$ & $1.02 \mathrm{E}+01$ & $2.83 \mathrm{E}+01$ & $1.46 \mathrm{E}+04$ & $1.20 \mathrm{E}+02$ & $1.30 \mathrm{E}+01$ & $<3.76 \mathrm{E}+00$ \\
\hline 1 & Blank & 300294836 & $<4.00 \mathrm{E}+00$ & $<4.00 \mathrm{E}+00$ & $<4.00 \mathrm{E}+00$ & $<4.00 \mathrm{E}+00$ & $1.11 \mathrm{E}+01$ & $<4.00 \mathrm{E}+00$ & $<4.00 \mathrm{E}+00$ & $<4.00 \mathrm{E}+00$ \\
\hline
\end{tabular}


Table 5-5. As-Received and Adjusted Measurements of the PCT Solutions

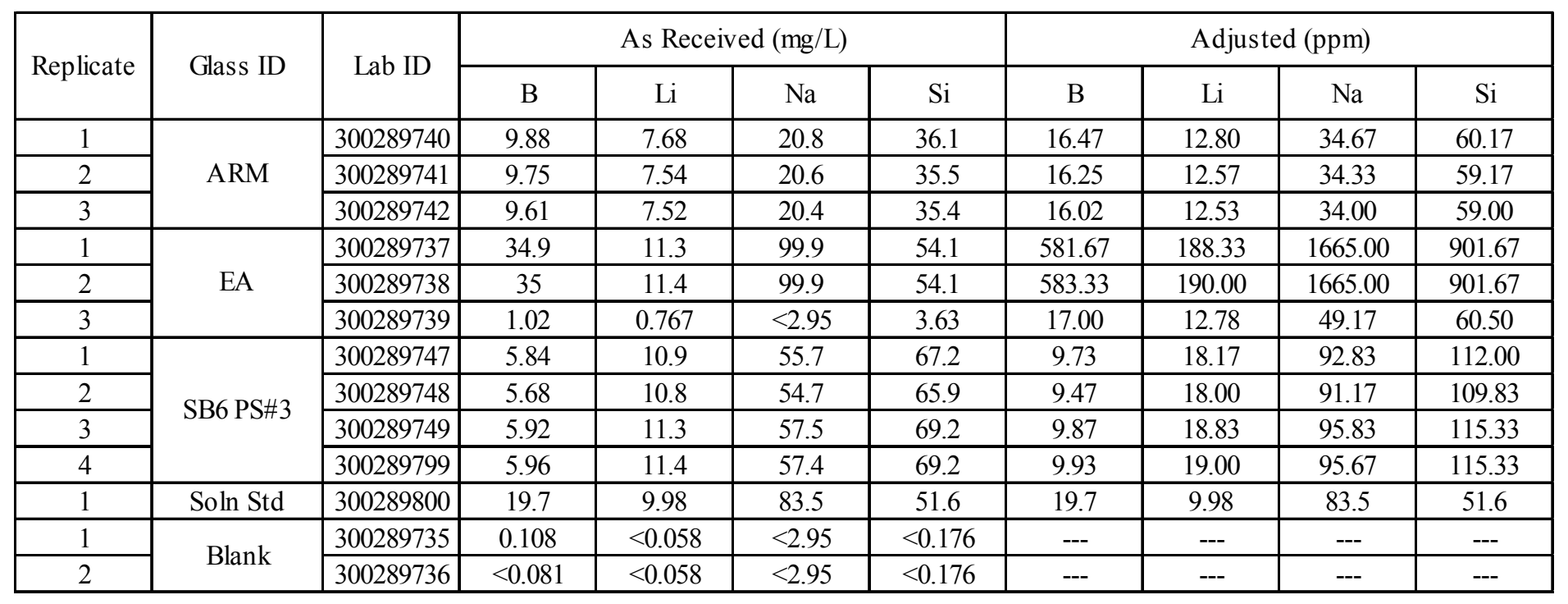

Table 5-6. Density Measurements

\begin{tabular}{|c|c|c|c|}
\hline Parameter & Reference Glass & SB6 PS\#2 & SB6 PS\#4 \\
\hline $\mathrm{m} 0(\mathrm{~g})$ & 32.105 & 31.746 & 32.085 \\
\hline $\mathrm{m} 1(\mathrm{~g})$ & 33.564 & 33.668 & 33.142 \\
\hline $\mathrm{m} 2(\mathrm{~g})$ & 82.828 & 82.808 & 82.573 \\
\hline $\mathrm{m} 3(\mathrm{~g})$ & 81.953 & 81.638 & 81.953 \\
\hline Vessel ID & 53 & 69 & 53 \\
\hline Density $\left(\mathbf{g} / \mathbf{c m}^{\mathbf{3}}\right)$ & 2.50 & 2.56 & 2.53 \\
\hline
\end{tabular}

Note: $\mathrm{m} 3$ was only measured once for vessel 53 
Table 5-7. SB6 Pour Stream REDOX Data

\begin{tabular}{|c|c|c|c|c|c|c|}
\hline Sample & Replicate & $\mathrm{Fe}^{2+}$ & $\sum \mathbf{F e}$ & $\mathrm{Fe}^{3+}$ & $\mathrm{Fe}^{2+} / \sum \mathrm{Fe}$ & $\mathrm{Fe}^{2+} / \mathrm{Fe}^{3+}$ \\
\hline EA & --- & 0.1429 & 0.761 & 0.6181 & 0.188 & 0.231 \\
\hline \multirow{2}{*}{ SB6 PS\#1 } & 1 & 0.2571 & 1.0508 & 0.7937 & 0.245 & 0.324 \\
\hline & 2 & 0.2627 & 1.0069 & 0.7442 & 0.261 & 0.353 \\
\hline EA & --- & 0.1941 & 1.0646 & 0.8705 & 0.182 & 0.223 \\
\hline \multirow{2}{*}{ SB6 PS\#2 } & 1 & 0.2398 & 0.8347 & 0.5949 & 0.287 & 0.403 \\
\hline & 2 & 0.3323 & 0.8946 & 0.5623 & 0.371 & 0.591 \\
\hline \multirow{2}{*}{ SB6 PS\#3 } & 1 & 0.2532 & 0.683 & 0.4298 & 0.371 & 0.589 \\
\hline & 2 & 0.2977 & 0.7978 & 0.5001 & 0.373 & 0.595 \\
\hline EA & --- & 0.1665 & 0.8694 & 0.7029 & 0.192 & 0.237 \\
\hline \multirow{2}{*}{ SB6 PS\#2 } & 3 & 0.1967 & 0.649 & 0.4523 & 0.303 & 0.435 \\
\hline & 4 & 0.2374 & 0.79 & 0.5526 & 0.301 & 0.430 \\
\hline \multirow{2}{*}{ SB6 PS\#3 } & 3 & 0.3354 & 0.8816 & 0.5462 & 0.380 & 0.614 \\
\hline & 4 & 0.3223 & 0.8608 & 0.5385 & 0.374 & 0.599 \\
\hline EA & --- & 0.1645 & 0.9301 & 0.7656 & 0.177 & 0.215 \\
\hline \multirow{3}{*}{ SB6 PS\#4 } & 1 & 0.3856 & 0.9236 & 0.5380 & 0.417 & 0.717 \\
\hline & 2 & 0.3272 & 0.7971 & 0.4699 & 0.410 & 0.696 \\
\hline & 3 & 0.3489 & 0.8875 & 0.5386 & 0.393 & 0.648 \\
\hline
\end{tabular}

Table 5-8. SB6 MFT REDOX Data

\begin{tabular}{|c|c|c|c|c|c|c|}
\hline Sample & Replicate & $\mathrm{Fe}^{2+}$ & $\sum \mathrm{Fe}$ & $\mathrm{Fe}^{3+}$ & $\mathrm{Fe}^{2+} / \sum \mathrm{Fe}$ & $\mathrm{Fe}^{2+} / \mathrm{Fe}^{3+}$ \\
\hline EA & --- & 0.1645 & 0.9301 & 0.7656 & 0.177 & 0.215 \\
\hline \multirow{3}{*}{ SB6 MFT 588-1 } & 1 & 0.238 & 0.499 & 0.2610 & 0.477 & 0.912 \\
\cline { 2 - 7 } & 2 & 0.203 & 0.429 & 0.2260 & 0.473 & 0.898 \\
\cline { 2 - 7 } SB6 MFT 588-2 & 3 & 0.262 & 0.483 & 0.2210 & 0.542 & 1.186 \\
\cline { 2 - 7 } & 2 & 0.206 & 0.402 & 0.1960 & 0.512 & 1.051 \\
\cline { 2 - 7 } & 3 & 0.225 & 0.547 & 0.3220 & 0.411 & 0.699 \\
\hline EA & --- & 0.088 & 0.42 & 0.4320 & 0.169 & 0.204 \\
\hline \multirow{3}{*}{ SB6 MFT 568A-A } & 1 & 0.06 & 0.293 & 0.2330 & 0.205 & 0.258 \\
\cline { 2 - 7 } & 2 & 0.059 & 0.402 & 0.3430 & 0.147 & 0.172 \\
\hline \multirow{3}{*}{ SB6 MFT 568A-B } & 2 & 0.061 & 0.453 & 0.3920 & 0.135 & 0.156 \\
\cline { 2 - 7 } & 3 & 0.022 & 0.5 & 0.4780 & 0.044 & 0.046 \\
\hline & 1 & 0.046 & 0.645 & 0.5990 & 0.071 & 0.077 \\
\hline \multirow{3}{*}{ SB6 MFT 568A-C } & 2 & 0.02 & 0.39 & 0.3700 & 0.051 & 0.054 \\
\cline { 2 - 7 } & 3 & 0.013 & 0.518 & 0.5050 & 0.025 & 0.026 \\
\cline { 2 - 7 } & & 0.011 & 0.473 & 0.4620 & 0.023 & 0.024 \\
\hline
\end{tabular}




\section{Distribution:}

J.W. Amoroso, 999-W

C. J. Bannochie, 773-42A

A. B. Barnes, 999-W

J. M. Bricker, 704-27S

M. A. Broome, 704-29S

C.L. Crawford, 773-42A

T.B. Edwards, 999-W

T. L. Fellinger, 704-26S

S. D. Fink, 773-A

K.M. Fox, 999-W

B. J. Giddings, 786-5A

J. M. Gillam, 766-H

C. C. Herman, 999-W

R. N. Hinds, 704-S

E. W. Holtzscheiter, 704-15S

J. F. Iaukea, 704-30S

P. R. Jackson, DOE-SR, 703-46A

C.M. Jantzen, 773-A

F.C. Johnson, 999-W

M. T. Keefer, 766-H

D.P. Lambert, $999-\mathrm{W}$

S. L. Marra, 773-A

D.W. McIlmoyle, 766-H

J.D. Newell, 999-W

J. E. Occhipinti, 704-S

J.M. Pareizs, 773-A

D. K. Peeler, 999-W

F. M. Pennebaker, 773-42A

J. W. Ray, 704-S

A.R. Shafer, 704-27S

H. B. Shah, 766-H

D. C. Sherburne, 704-S

A. V. Staub, 704-27S

M. E. Stone, 999-W

K. H. Subramanian, 766-H

J. P. Vaughan, 773-41A

W. R. Wilmarth, 773-A

J.R. Zamecnik, 999-W 